\title{
Correction to: Basal ganglia calcifications (Fahr's syndrome): related conditions and clinical features
}

\author{
Giulia Donzuso ${ }^{1} \cdot$ Giovanni Mostile $^{1} \cdot$ Alessandra Nicoletti $^{1} \cdot$ Mario Zappia $^{1}$ (D
}

Published online: 23 August 2019

(C) The Author(s) 2019

\section{Correction to: Neurological Sciences (2019) https://doi.org/10.1007/s10072-019-03998-x}

The article "Basal ganglia calcifications (Fahr's syndrome): related conditions and clinical features, written by Giulia Donzuso, Giovanni Mostile, Alessandra Nicoletti, and Mario Zappia", was originally published electronically on the publisher's internet portal (currently SpringerLink) on 3 July 2019 without open access. With the author(s)' decision to opt for Open Choice the copyright of the article changed on August 2019 to (CThe Author(s) 2019 and the article is forthwith distributed under the terms of the Creative Commons Attribution 4.0 International License (http://creativecommons.org/ licenses/by/4.0/), which permits use, duplication, adaptation, distribution and reproduction in any medium or format, as long as you give appropriate credit to the original author(s) and the source, provide a link to the Creative Commons license and indicate if changes were made.

The original article has been corrected.

Open Access This article is distributed under the terms of the Creative Commons At tribution 4.0 International License (http:// creativecommons.org/licenses/by/4.0/), which permits unrestricted use, distribution, and reproduction in any medium, provided you give appropriate credit to the original author(s) and the source, provide a link to the Creative Commons license, and indicate if changes were made.

Publisher's note Springer Nature remains neutral with regard to jurisdictional claims in published maps and institutional affiliations.

The online version of the original article can be found at https://doi.org/ 10.1007/s10072-019-03998-x

Mario Zappia

m.zappia@unict.it

1 Department “GF Ingrassia”, Section Neuroscience, University of Catania, Via Santa Sofia 78, 95123 Catania, Italy 